\title{
THE TRANSPORT OF SHEEP AND GOAT SPERMATOZOA IN THE EWE
}

\author{
J. L. HANCOCK AND P. T. MaGOVERN \\ A.R.C., Animal Breeding Research Organisation, Edinburgh \\ (Received 17th June 1967)
}

\begin{abstract}
Summary. Counts were made of the numbers of spermatozoa in the Fallopian tubes of ewes $24 \mathrm{hr}$ after mating or after insemination with either sheep or goat semen.

Spermatozoa were recovered from all five mated ewes (10/10 tubes), from all eight ewes inseminated with sheep semen (13/15 tubes) and from four of eight ewes inseminated with goat semen (7/16 tubes). The calculated mean numbers of spermatozoa per tube for the three groups were, respectively, 55,332 $\pm 22,434,2937 \pm 889$ and $4640 \pm 1958$. The low fertilization rate of ewes inseminated with goat semen cannot be explained by failure of the goat spermatozoa to reach the Fallopian tube.
\end{abstract}

\section{INTRODUCTION}

Fertilization commonly occurs when goats are inseminated with sheep semen, but usually fails to do so when sheep are inseminated with goat semen (Warwick \& Berry, 1949; Bowerman \& Hancock, 1963). The experiments recorded here were undertaken to examine the possibility that this low rate of fertilization in sheep is due to a specific failure in the transport of the heterologous spermatozoa. For this purpose, counts were made of the numbers of spermatozoa present in the Fallopian tubes of sheep $24 \mathrm{hr}$ after mating and after insemination with either sheep or goat semen. Data from the mated sheep were used as an index of the efficiency of the method used to recover and count the spermatozoa.

\section{MATERIALS AND METHODS}

The females were Welsh and Scottish Blackface ewes from the A.B.R.O. flock. The males were Scottish Blackface $\left(S_{1}\right.$ and $\left.S_{3}\right)$ and Merino $\left(S_{2}\right)$ rams and cross-bred goats $\left(G_{1}\right.$ and $\left.G_{2}\right)$.

Vasectomized rams, marked with coloured raddle, were used to detect oestrus, the ewes being inspected once daily. Oestrous ewes were mated once with a fertile male or were inseminated once with either goat or sheep semen. For this purpose semen was collected with an artificial vagina and maintained at $37^{\circ} \mathrm{C}$ in a water bath before use. Semen was used for insemination only if its motility was considered to be satisfactory. The density was determined by haemocytometer counts and the percentage of dead spermatozoa was determined from counts of eosinophilic spermatozoa in smears stained with nigrosin and eosin (Hancock, 1952). 
For insemination the ewe was restrained on her back with her hind quarters raised. A perspex speculum with a built-in light source was used to locate the cervix. Ewes in both groups were inseminated into the external os with $0.5 \mathrm{ml}$ of undiluted semen. Precautions were taken to avoid temperature shock to the semen during collection and insemination.

In the preliminary experiments the direction of flushing was varied, but in the main experiment all recoveries were made by flushing from the ovarian to the uterine end of the Fallopian tubes using the technique described below.

Spermatozoa were recovered at laparotomy approximately $24 \mathrm{hr}$ after mating or insemination. The anaesthetic and surgical techniques were the same as those used by Hancock \& Hovell (1961). The Fallopian tubes were flushed with $1.0 \mathrm{ml}$ phosphate buffered saline (PBS) by inserting a polythene catheter attached to a hypodermic syringe, into the ovarian end of the tube. The fluid was collected through a glass catheter inserted into the uterine end of the Fallopian tube, into a siliconized glass vessel and then transferred to a counting chamber. The spermatozoa were allowed to settle for 10 to $15 \mathrm{~min}$ before counting. The observer making the counts was unaware of the identity of the samples.

The counting chamber was made by cementing two glass blocks $0.7 \mathrm{~mm}$ thick to a microscope slide. In use, a coverslip was mounted on the glass blocks to form a chamber approximately $1 \mathrm{~cm}$ square. An 8-mm phase-contrast objective was used to count the spermatozoa in a total of twenty-five fields of view (five sets of five contiguous fields, each set of five fields from a different region of the chamber). The measured diameter of the microscope field was $0.56 \mathrm{~mm}$ and the total volume of fluid per field was therefore $0.1725 \mathrm{~mm}^{3}$. A count of one spermatozoon in the total of twenty-five fields is, therefore, equivalent to a total of 232.5 spermatozoa in the Fallopian tube, assuming that all spermatozoa present were suspended in the $1.0 \mathrm{ml}$ saline used for flushing.

\section{RESULTS}

In a preliminary experiment all three mated ewes yielded spermatozoa from both tubes. Spermatozoa were recovered from five out of eleven ewes $(10 / 22$ tubes) inseminated with sheep semen and from four out of thirteen ewes (4/26 tubes) inseminated with goat semen. The mean number of spermatozoa per tube recovered from the mated ewes was 57,195 , from the ewes inseminated with sheep semen 15,996 and from the ewes inseminated with goat semen 4534 .

A further experiment was designed to examine factorially the difference in numbers of spermatozoa in the Fallopian tubes of the mated group and of sheep inseminated with either sheep or goat semen. Ewes available for insemination were to be allocated in turn to one of the six experimental groups (one mated ewe and one inseminated ewe for each of the two rams $S_{1}$ and $S_{2}$, and one inseminated ewe for each of the two male goats $G_{1}$ and $G_{2}$ ). It was the intention to make three replicas of each group of six. The plan had to be modified when one ram, $S_{2}$, failed to mate and had to be replaced by $S_{3}$; but the general form of the plan was retained.

Data from four additional inseminated ewes are included in the results in Table 1. 
TABLE 1

THE RESULTS OF EXAMINATIONS FOR THE PRESENCE OF SPERMATOZOA IN WASHINGS FROM THE FALLOPIAN TUBES OF MATED EWES AND OF EWES INSEMINATED EITHER WITH RAM OR GOAT SEMEN USING THREE RAMS $\left(s_{1}, s_{2}\right.$ AND $\left.s_{3}\right)$ AND TWO GOATS $\left(G_{1}\right.$ AND $\left.g_{2}\right)$

\begin{tabular}{|c|c|c|c|c|c|c|c|c|c|c|c|}
\hline & & & & & \multicolumn{7}{|c|}{ Inseminations } \\
\hline & \multicolumn{4}{|c|}{ Matings } & \multicolumn{4}{|c|}{ Sheep semen } & \multicolumn{3}{|c|}{ Goat semen } \\
\hline & $S_{1}$ & $S_{2}$ & $S_{3}$ & $t$ & $S_{1}$ & $S_{2}$ & $S_{3}$ & $t$ & $G_{1}$ & $G_{2}$ & $t$ \\
\hline $\begin{array}{l}\text { No. of ewes } \\
\text { examined/No. of } \\
\text { ewes yielding } \\
\text { spermatozoa }\end{array}$ & $3 / 3$ & $1 / 1$ & $1 / 1$ & $5 / 5$ & $4 / 4$ & $2 / 2$ & $2 / 2$ & $8 / 8$ & $2 / 4$ & $2 / 4$ & $4 / 8$ \\
\hline $\begin{array}{l}\text { No. of tubes } \\
\text { examined/No. of } \\
\text { tubes yielding } \\
\text { spermatozoa }\end{array}$ & $6 / 6$ & $2 / 2$ & $2 / 2$ & $10 / 10$ & $7 / 8$ & $2 / 3^{*}$ & $4 / 4$ & $13 / 15^{*}$ & $4 / 8$ & $3 / 8$ & $7 / 16$ \\
\hline
\end{tabular}

* One tube could not be flushed.

TABLE 2

THE NUMBER OF SPERMATOZOA RECOVERED IN SAMPLES FROM THE FALLOPLAN TUBES OF MATED EWES AND FROM EWES INSEMINATED WITH SHEEP OR GOAT SEMEN AND THE SEMEN CHARAGTERISTICS OF THE EJAGULATES USED FOR INSEMINATION

\begin{tabular}{|c|c|c|c|c|c|}
\hline \multirow[t]{2}{*}{ Male } & \multirow{2}{*}{$\begin{array}{c}\text { Mating }(M) \\
\text { or insemina- } \\
\text { tion }(A I)\end{array}$} & \multirow{2}{*}{$\begin{array}{c}\text { Sperm } \\
\text { concentration } \\
\left(/ \mathrm{mm}^{3} / 10^{9}\right)\end{array}$} & \multirow{2}{*}{$\begin{array}{l}\text { Percentage } \\
\text { of dead } \\
\text { spermatozoa }\end{array}$} & \multicolumn{2}{|c|}{$\begin{array}{l}\text { No. of spermatozoa in } \\
\text { samples from left }(L) \\
\text { and right }(R) \\
\text { Fallopian tubes }\end{array}$} \\
\hline & & & & $L$ & $R$ \\
\hline $\mathrm{S}_{1}$ & $\begin{array}{l}\mathbf{M} \\
\mathbf{M} \\
\mathbf{M} \\
\text { AI } \\
\text { AI } \\
\text { AI } \\
\text { AI }\end{array}$ & $\begin{array}{l}4 \cdot 16 \\
2 \cdot 84 \\
2 \cdot 52 \\
3 \cdot 12\end{array}$ & $\begin{array}{r}5 \cdot 5 \\
11 \cdot 0 \\
6 \cdot 5 \\
3 \cdot 5\end{array}$ & $\begin{array}{r}22 \\
359 \\
47 \\
18 \\
1 \\
10 \\
7\end{array}$ & $\begin{array}{r}123 \\
980 \\
73 \\
25 \\
0 \\
12 \\
1\end{array}$ \\
\hline$S_{2}$ & $\begin{array}{l}\text { M } \\
\text { AI } \\
\text { AI }\end{array}$ & $\begin{array}{l}3.12 \\
1.74\end{array}$ & $\begin{array}{r}11.0 \\
4.0\end{array}$ & $\begin{array}{l}2 \\
1 \\
0\end{array}$ & $\begin{array}{l}8 \\
-^{*}\end{array}$ \\
\hline $\mathrm{S}_{3}$ & $\begin{array}{l}\text { M } \\
\text { AI } \\
\text { AI }\end{array}$ & $\begin{array}{l}2 \cdot 84 \\
3.46\end{array}$ & $\begin{array}{l}7 \cdot 5 \\
3 \cdot 5\end{array}$ & $\begin{array}{r}397 \\
13 \\
29\end{array}$ & $\begin{array}{r}375 \\
26 \\
46\end{array}$ \\
\hline $\mathrm{G}_{\mathbf{n}}$ & $\begin{array}{l}\text { AI } \\
\text { AI } \\
\text { AI } \\
\text { AI }\end{array}$ & $\begin{array}{l}3 \cdot 02 \\
3 \cdot 50 \\
4 \cdot 00 \\
2 \cdot 22\end{array}$ & $\begin{array}{r}7 \cdot 5 \\
27 \cdot 5 \\
13 \cdot 5 \\
12 \cdot 5\end{array}$ & $\begin{array}{r}0 \\
0 \\
3 \\
11\end{array}$ & $\begin{array}{r}0 \\
0 \\
1 \\
28\end{array}$ \\
\hline $\mathbf{G}_{2}$ & $\begin{array}{l}\text { AI } \\
\text { AI } \\
\text { AI } \\
\text { AI }\end{array}$ & $\begin{array}{l}5 \cdot 44 \\
3 \cdot 68 \\
3 \cdot 14 \\
4 \cdot 18\end{array}$ & $\begin{array}{l}7 \cdot 0 \\
7 \cdot 0 \\
5 \cdot 0 \\
9 \cdot 0\end{array}$ & $\begin{array}{r}0 \\
54 \\
0 \\
0\end{array}$ & $\begin{array}{r}0 \\
42 \\
1 \\
0\end{array}$ \\
\hline
\end{tabular}

* Could not be flushed. 
Spermatozoa were recovered from all five mated ewes (10/10 tubes) and from all eight ewes inseminated with sheep semen (13/15 tubes) but from only four of the eight ewes inseminated with goat semen (7/16 tubes). Excluding tubes which yielded no spermatozoa, the calculated mean numbers of spermatozoa recovered per tube were 55,332 $\pm 22,434$ from the mated ewes, $2937 \pm 889$ from the ewes inseminated with sheep semen and $4640 \pm 1958$ from the ewes inseminated with goat semen.

The number of spermatozoa recovered from mated ewes is significantly higher than that from ewes inseminated with sheep semen $(P<0.02)$; the mean numbers from the two inseminated groups do not differ significantly $(P>0 \cdot 4)$. The proportion of tubes in which spermatozoa were found is significantly greater in the sheep-inseminated ewes than in the goat-inseminated ewes $\left(\chi_{(1)}^{2}=6.05 ; P<0.02\right)$.

Sperm concentrations and the percentages of dead spermatozoa in the semen used for inseminations are given in Table 2. The quality of the semen from both species was largely the same; and although the percentage of dead spermatozoa was somewhat higher in the goat semen this is compensated for by the higher density of the goat semen compared to that of the sheep. The difference between the two inseminated groups in the proportion of Fallopian tubes yielding spermatozoa clearly cannot be ascribed to superior characteristics of the sheep semen.

\section{DISCUSSION}

The numbers of spermatozoa found in the Fallopian tubes of ewes $24 \mathrm{hr}$ after mating are considerably higher than those previously recorded (Warbritton, McKenzie, Berliner \& Andrews, 1937; Braden \& Austin, 1954; Mattner, 1963).

It is clear that, in terms of the number of spermatozoa found in the Fallopian tubes, the artificial insemination technique used here is less efficient than natural mating; although the evidence is that the method is effective when judged by the number of goats conceiving to insemination even with heterologous spermatozoa (see Hancock, McGovern \& Stamp, 1968). Comparing mated ewes and ewes inseminated with ram semen it seems unlikely that the smaller number of spermatozoa reaching the Fallopian tubes of inseminated ewes is due to the smaller volume of semen inseminated artificially. The relative failure of sperm transport in the inseminated group may be a result of the absence of normal mating stimuli together with the excessive amount of handling and disturbance to the ewe which is unavoidable with the insemination technique. Mattner (1963) found that sperm transport was adversely affected by disturbing ewes immediately after they had mated. However, the effects which he observed were only transitory and were not detectable $24 \mathrm{hr}$ after mating, i.e. the time at which the observations recorded here were made.

With regard to transport of the heterologous spermatozoa the results show that goat spermatozoa were found in the Fallopian tubes of half the ewes inseminated with goat semen; and, although the proportion of tubes yielding spermatozoa was smaller than in those receiving sheep semen, the findings are inconsistent with the suggestion that failure of transport of the heterologous 
spermatozoa is wholly responsible for the failure of fertilization in sheep inseminated with goat semen.

The occurrence of fertilization following insemination with heterologous spermatozoa provides clear evidence of successful transport of such spermatozoa in a number of species (see Chang \& Hancock, 1967) and there is other evidence of the successful transport of heterologous (rat) spermatozoa in the sheep (Phillips \& Andrews, 1937).

\section{REFERENCES}

Bowerman, H. R. L. \& Hancock, J. L. (1963) Sheep-goat hybrids. F. Reprod. Fert. 6, 326.

Braden, A. W. H. \& Austin, C. R. (1954) The numbers of sperms about the eggs in mammals and its significance for normal fertilisation. Aust. F. biol. Sci. 7, 543 .

Chang, M. C. \& Hancock, J. L. (1967) Experimental hybridisation. In: Comparative Aspects of Reproductive Failure. Ed. K. Benirschke. Springer, New York.

Hancock, J. L. (1952) The morphology of bull spermatozoa. F. exp. Biol. 29, 445.

Hancock, J. L. \& Hovell, G. J. R. (1961) Transfer of sheep ova. 7. Reprod. Fert. 2, 295.

Hancock, J. L., McGovern, P. T. \& Stamp, J. T. (1968) Failure of gestation of goat $x$ sheep hybrids in goats and sheep. 7. Reprod. Fert. Suppl. 3, 29.

Mattner, P. E. (1963) Spermatozoa in the genital tract of the ewe. II. Distribution after coitus. Aust. 7. biol. Sci. 16, 688.

Phillips, R. W. \& Andrews, F. N. (1937) The speed of travel of ram spermatozoa. Anat. Rec. 68, 127.

Warbritton, V., McKenzie, F. F., Berliner, V. \& Andrews, F. N. (1937) Sperm survival in the genital tract of the ewe. Rec. Proc. Am. Soc. Anim. Prod. 30, 142.

WARWICK, B. L. \& BERRY, R. O. (1949) Inter-generic and intra-specific embryo transfers in sheep and goats. 7. Hered. 40, 297. 